\title{
EFFECT OF SMART IRRIGATION CONTROLLERS UNITS ON THE PERFORMANCE AND PRODUCTIVITY OF SUBSURFACE AND SURFACE DRIP IRRIGATION SYSTEMS FOR TOMATO CROP IN ARID REGIONS \\ El Marazky, M. S. A. ${ }^{1,2}$ \\ ${ }^{1}$ Department of Agricultural Engineering- College of Food and Agriculture Sciences \\ King Saud University- Riyadh 11451, Kingdom of Saudi Arabia \\ 2 Permanent address: Agriculture Engineering Research Institute, Agriculture Research Center- (AEnRI) \\ P. O. Box 256- Cairo, Dokki - Giza - Egypt
}

\begin{abstract}
Two types of Smart irrigation controller units (SIC) for scheduling irrigation water were studied under Saudi Arabia's present water crisis scenario. They were oprated based on evapotranspiration rate (ETR) promising tools for scheduling irrigation requirement by means of quantifying water required by plants to targeted water savings. The purpose of this study is to evaluate the effectiveness of these technologies, i.e. SmartLine and Hunter on irrigation amount applied, and compared with conventional irrigation scheduling methods as a control treatment. These two types of smart irrigation were implemented and tested under surface drip irrigation (DI) and subsurface drip irrigation (SDI) for tomato crop (Nema tomato $\mathrm{cv}$.) in arid region. The obtained results showed that there are significant differences in the amount of applied water and the yield for the three irrigation scheduling methods. The data were normalized to produce a tomato crop yield per $\mathrm{mm}$ water depth applied, providing values of 66.50 (48.91), 62.74 (47.75), and $35.54(28.21) \mathrm{kg} / \mathrm{mm}$ for the Hunter, SmartLine, and control systems, respectively, under SDI and (DI). The results also revealed that plant the growth parameters and water conservation were significantly affected by Hunter controller and SDI. The irrigation water use efficiency (IWUE) under Hunter controller under SDI was generally higher $\left(15.92 \mathrm{~kg} \mathrm{~m}^{-3}\right)$ as compared with that under control DI $\left(6.76 \mathrm{~kg} \mathrm{~m}^{-3}\right)$, resulting in maximal IWUE for both growing seasons (average $15.82 \mathrm{~kg} \mathrm{~m}^{-3}$ ). The application of Hunter controller under SDI technology therefore provides significant advantages in terms of both crop yield and IWUE. In addition, Hunter controller under SDI conserves $25 \%$ of the total irrigation water as compared with the control treatment, and simultaneously generates higher total yields. Generally, it can be mentioned that Hunter Pro-C system saved more water and produced more yield with the highest use irrigation efficiency (IWUE) under SDI compared with the other irrigation scheduling methods. Moreover, the results indicated that the SDI system produced a higher yield and IWUE than DI. Ultimately, these technology is recommended for efficient automated irrigation systems and the Hunter Pro-C technique may provide a valuable tool for conserving water planning and irrigation scheduling for tomato and which is extendable to other similar agricultural crops.
\end{abstract}

Keywords: Smart irrigation; ET controllers; drip irrigation, subsurface drip irrigation systems; irrigation water use efficiency; arid region, tomato yields. 


\section{INTRODUCTION}

Improvements for saving water in irrigated agriculture and thereby improving water use efficiency are a paramount importance in water-scarce regions. Therefore, use of new irrigation technologies in agriculture have aimed at increasing crop production, and in these respect new educe applied water in irrigation are a great importance. With increasing demands on limited water resources and the need of minimizing adverse environmental consequences of irrigation, micro- irrigation and smart irrigation technologies will undoubtedly play an important role in the future of the Saudi Arabia agriculture. It provides many unique agronomic, water and energy conservation benefits that address many of the challenges facing irrigated agriculture.

Wang et al., (2009) reported that the, micro-irrigation methods, such as drip irrigation, were adopted for field experiments of food crops. Hassanli et al., (2009) compared three irrigation methods, drip, subsurface and furrow irrigation. The results showed that the maximum amount of water with highest water use efficiency (WUE) was provided through subsurface irrigation system. Khairy et al., (2009) found that the subsurface irrigation gives the highest yield when compared with surface drip irrigation system for tomato in sandy soil. Al-Omran et al., (2010) concluded that the subsurface drip irrigation increased the yield and WUE of the tomato crop resulted in saving of applied irrigation water by creating a good moisture distribution in the root zone depth.

Irrigation scheduling remains a reliable technique for applying the adequate needed amount of water on extra time. Automated irrigation systems based on crop needs of water are providing maximum possible efficiency of water use (Munoz-Carpena et al., 2003; Munoz-Carpena et al., 2005a and Munoz-Carpena et al. 2005b). There are three methods for matching irrigation with crop water requirements: the weather-based methods using evapotranspiration, ET (Allen et al. 1998), the soil water-based methods using soil moisture sensors (Evett 2008) and the soil-water-balance calculations and plant stress-sensing techniques (Jones 2004). The Smart Water Application Technology Committee of the Irrigation Association (IA, 2011) defines 'smart controllers' as those technologies which estimate or measure depletion of soil moisture in order to replenish water as needed. Vellidis, et al, (2008) conducted a study using intelligent devices to measure soil moisture and soil temperature. Intelligent irrigation technologies were evaluated in Dookie, Egypt and resulted water saving up to $38 \%$ over conventional irrigation (Dassanayake et al. 2009). They pointed out that the intelligent sensors can be integrated with intelligent irrigation techniques to conserve water and time.

The smart irrigation controllers SIC integrate many disciplines to produce a significant improvement in crop production and resource management (Norum and Adhikari 2009). Mayer et al., (2009) found that SIC reduced irrigation by $6.1 \%$; and it was found that $56.7 \%$ of the sites were responsible for a significant decrease in irrigation application, while $41.8 \%$ 
were responsible for a significant increase. Davis et al., (2010) demonstrated that the SIC applied approximately half of the irrigation calculated for the theoretical requirement for each irrigation event, on average, irrigation adequacy decreased when the SIC were allowed to irrigate any day of the week. Al-Ghobari and Fawzi (2011) reported that the initial results indicate that up to $25 \%$ water saving by intelligent irrigation system (IIS) compared to control method, while maintaining competing yield. Davis and Dukes (2012) found that SIC can match irrigation application with seasonal demand and in particular reduce irrigation in the winter when plant demands are dramatically reduced. In addition, they point out that when SIC are applied to sites, irrigating at levels less than plant demand, those SIC will likely increase irrigation. Mohammad et al. (2013) and Al-Ghobari et al. (2013) examined two-year field study using the IIS for irrigation water scheduling, they found that the IIS offered a significant advantage in managing the irrigation of tomato and wheat crops in both seasons under severely arid conditions. Consequently, the results show that the IIS had significant effects on water use efficiency (WUE). The IIS technique conserved irrigation water by $26 \%$ compared to the amount provided by the control method. The use of frequent, but low water application volumes is superior to the more traditional scheduling of few applications of large irrigation volumes in terms of IWUE (Locascio 2005; Zotarelli et al., 2009; Dukes et al., 2010).

Adoption of modern water-saving technology is often cited as a key to increasing water use efficiency while maintaining current levels of production (Green et al., 1996). The main aim of these techniques has been to achieve efficient water delivery and high productivity while minimizing water (Acar et al., 2010). Therefore, owing to prevailing conditions and water shortages, the optimum irrigation schedules for tomato crop in the arid region should be determined. Though, this technology has not been tested with field crop in a hyper arid region such as Saudi Arabia. The main objective of this study was to determine the effectiveness of two SIC i.e. (SmartLine and Hunter) in terms of the amount of irrigation applied to conserve water use for tomato crop irrigation and irrigation water use efficiency (IWUE) in arid region under surface and subsurface drip irrigation systems.

\section{MATERIALS AND METHODS}

\section{Site description}

This study was performed at the experimental farm of the College of Food and Agriculture Sciences of King Saud University, Riyadh $24^{\circ} 43^{\prime} \mathrm{N}$ latitude, $46^{\circ} 43^{\prime}$ E longitude and $635 \mathrm{~m}$ altitude above the sea level during the two spring seasons of 2013 and 2104. Generally, the climate in this region is classified as arid, and the climatological data, such as air temperature, relative humidity, rain, solar radiation, and wind speed were measured at the experimental site during the experimental works. The weather station was installed at the field site and used to measure the climate 
parameters that were used to compute evapotranspiration (ETo). The distance from the weather station to the sample plots was less than $10 \mathrm{~m}$. Two types of smart irrigation controllers (SmartLine SL 1600 and Hunter proc) were installed at tomato crop fields. Each system was programmed in situ, taking into account the crop type and environmental conditions of the area.

\section{Experimental layout and treatments}

The study area was $2000 \mathrm{~m}^{2}(80 \times 25 \mathrm{~m})$ assigned for the experiments, and divided into three blokes separated with buffer zones of $5 \mathrm{~m}$ wide (Fig.1). Two of these blocks are divided into six sub plots, and the third one is divided into two plots as control for comparison proposes. Each sub plot size was $7 \mathrm{~m} \times 10 \mathrm{~m}\left(70 \mathrm{~m}^{2}\right)$. Three sub plots from each block were irrigated by subsurface drip irrigation (SDI) and another three by drip irrigation (DI). The total sub plots of the experiments were 18, six (1 - 6) were controlled and irrigated automatically by Smart line controller, while the other six $(7-12)$ were controlled and irrigated automatically by Hunter. While plots $(13,14$ and 15) and plots (16, 17 and 18) managed manually in the two treatments, DI and SDI respectively as control treatment (Fig. 1).

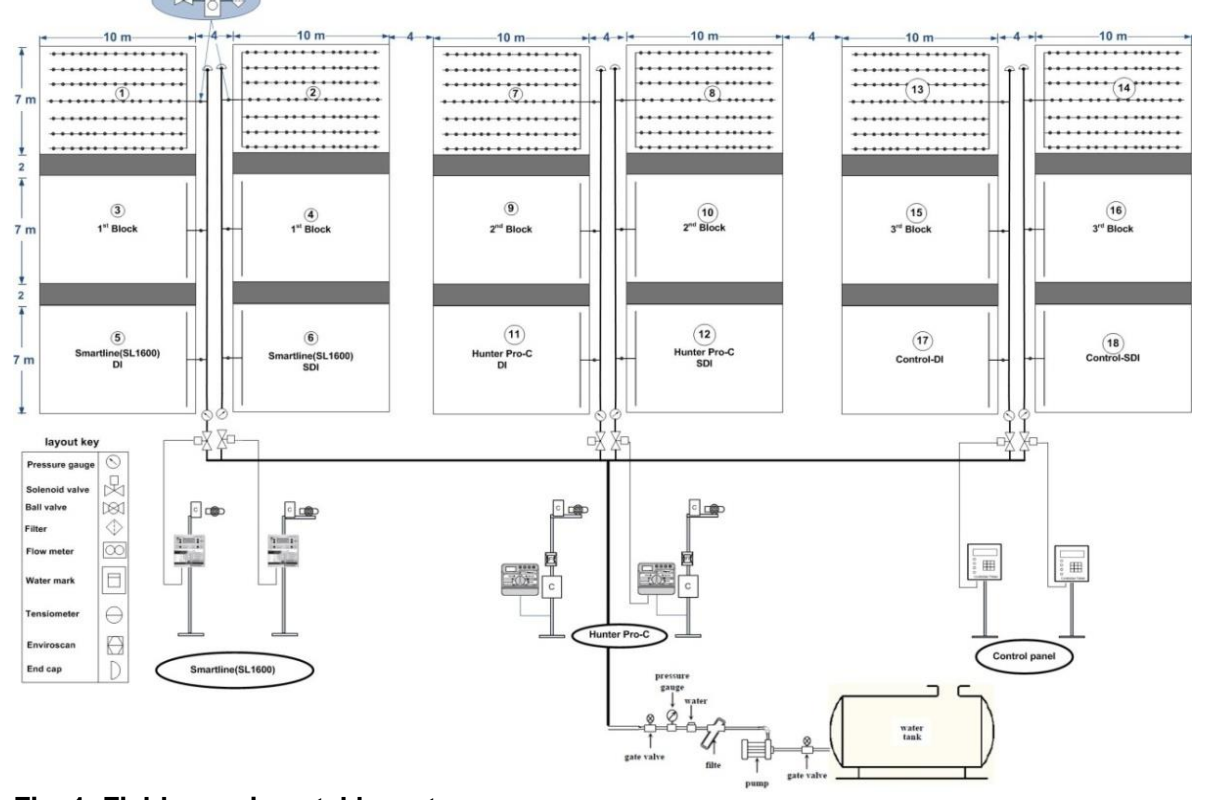

Fig. 1. Field experimental layout

The field was cultivated with tomato crop (Nema tomato cv.). Two of the three fields were irrigated automatically by modern electrical controllers, via smart irrigation controllers (SIC) namely SmartLine, SL-1600 ${ }^{1}$ (SL) and Hunter Pro- $\mathrm{C}^{1}(\mathrm{H})$ respectively. This system is not considered the best system, but it was inexpensive and available on the local market. Each was sub divided into two plots, DI and SDI irrigation systems, and all plots were provided with seven parallel drip lines, $10 \mathrm{~m}$ long, and one meter a part (Fig. 
1). The third plot was irrigated manually with irrigation control system (ICS) based on ETc values using climatological data from the weather station located treatment $10 \mathrm{~m}$ of the experimental site. Reference for about evapotranspiration (ETo) was computed for a hypothetical reference crop according to the methodology of FAO paper no. 56 (Allen et al., 1998). The soil type in the study area was sandy loam, and some physical and chemical properties of the experimental field soil are presented in Table (1).

Table 1. Physical and chemical properties of different soil layers at the experimental area

\begin{tabular}{|c|c|c|c|c|c|c|c|c|c|c|c|c|c|c|}
\hline \multirow{2}{*}{$\begin{array}{c}\text { Soil } \\
\text { depth } \\
\text { (cm) }\end{array}$} & \multicolumn{3}{|c|}{$\begin{array}{c}\text { Particle size } \\
\text { distribution (\%) }\end{array}$} & \multirow{2}{*}{$\begin{array}{c}\text { Soil } \\
\text { type } \\
\text { texture }\end{array}$} & \multirow{2}{*}{ pH } & \multirow{2}{*}{$\begin{array}{l}\text { EC } \\
\mathrm{ds} / \mathrm{m}\end{array}$} & \multicolumn{4}{|c|}{ Cations meq/l } & \multicolumn{3}{|c|}{ Anions meq/l } & \multirow{2}{*}{ - } \\
\hline & Sand\% & Sil & Clay\% & & & & C & & + & $\mathbf{K +}$ & HCO- & $\mathrm{Cl}$ & SO42- & \\
\hline $0-20$ & 74.80 & 12.72 & 12.48 & SL & 7.27 & 1.67 & 10.07 & 3.80 & 4.70 & 0.47 & 5.23 & 7.07 & 6.47 & 23.83 \\
\hline $20-40$ & 70.58 & 13.37 & 16.05 & SL & 7.43 & 1.43 & 6.77 & 3.43 & 4.17 & 0.43 & 3.87 & 5.50 & 5.87 & 26.33 \\
\hline $40-60$ & 67.08 & 15.73 & 17.20 & $\overline{S L}$ & 7.43 & 2.30 & 14.17 & 6.43 & 5.87 & 0.70 & 3.93 & 8.47 & 13.57 & 30.33 \\
\hline & 7082 & 1394 & 1521 & 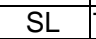 & 70 & 180 & 402 & 455 & 101 & 553 & 434 & 701 & 864 & 83 \\
\hline
\end{tabular}

\begin{tabular}{|l|l|l|l|l|l|l|l|l|l|l|l|l|l|l|}
\hline Average & 70.82 & 13.94 & 15.24 & $\mathrm{SL}$ & 7.38 & 1.80 & 10.34 & 4.55 & 4.91 & 0.53 & 4.34 & 7.01 & 8.64 & 26.83 \\
\hline
\end{tabular}

SL= Sandy loam

Both the DI and SDI systems consisted of $16 \mathrm{~mm}$ inside diameter thin-wall drip lines with welded-on emitters (NETFIM) separated with $1 \mathrm{~m}$ distances and mounted with 20 drippers. Drip lines are mounted with emitters of a nominal discharge $3.5 \mathrm{~L} / \mathrm{h}$ at a design pressure of $80 \mathrm{kPa}$. The drip lines in each plot were connected to a common sub-main irrigation line at the inlet side of the plot and a common flush line and flush valve at the distal end of the plot. These lines for both (DI and SDI) were provided with polyethylene laterals fitted with emitters. The laterals were laid on leveled ground, and connected to PVC sub main pipes, which were connected to galvanize steel main line. The main lines were connected to the pump unit, equipped with pressure regulators, and flow meters to measure the amount of water added for each plot.

The drip system was evaluated in the field according to the methodology of ASABE Standard, S346.1 (2007). The smart irrigation controller is required a complete database for each station (or "zone") to be controlled. Every controller must be carefully observed and monitored after initial installation for the best results. Generally, most systems require adjustment, at the station level, for some time after installation to provide ideal results. Evaluation tests were conducted by checking the performance index values under the operating field conditions. These evaluation values must be within acceptable limits with good water distribution uniformity (over $90 \%)$.

Smart controller installation setup

The SIC was installed according to the manufacturer's instructions in the field for the planned experiments. It can be customized by station (or "zone") for specific plants, soils and drip types. Auto adjust operation requires that the SmartLine controller is provided with the latitude location of the site. The other data required were auto adjusting data such as irrigation system 
type; plant type, soil type and other information to be able to calculate run times for each zone. Irrigation system type is set as drip irrigation, which apply 1.1 inches per hour $(2.794 \mathrm{~cm} / \mathrm{hr})$. Then the type of plant to be watered by each zone must be specified in the SmartLine controller. The system provided with a list of plant types to be selected. In this study the native plant zone is assigned due to its flexibility in adjusting the percentage ranging from 10 to 300. In addition, soil type and degree of slope are also required for SmartLine controller to automatically calculate the maximum length of a zone run time before pausing watering for a calculated period to allow the water to soak into the soil. Therefore, sand type was selected from the three options (clay, loam and sand).

The Hunter controller based on ET System which uses sensors to calculates the daily ETc rate of tomato crop installed in the field, and ET Module interface enclosure, installed next to the irrigation controller. This type of system uses digital electronic controllers, modules, and its platform can be wired to an ET module. Then the ET sensor applies the command of initiating and stopping irrigation event to the individual fields (zones) of irrigation. The IIS automatically calculates crop evapotranspiration (ETc) for local microclimates based on the modified Penman equation of FAO paper no. 56 (Allen et al., 1998) and creates a scientific program. The ET Module has settings to customize each zone's plant, soil, and irrigation types, so that ET data can be applied proportionately for each unique irrigation requirement downloads to the controller.

Field operation, measurement of plant growth, yield and fruit quality traits

The field allocated for SDI irrigation has been excavated to a depth of $15 \mathrm{~cm}$ below the soil surface to accommodate subsurface irrigation pipes. The sequence steps of field preparation were completing installation of the rest of irrigation network, which consist of valves, flow meter and pressure meters. Tomato plants (Nema tomato cv.) were transplanted into the fields on February 7, 2013 and February 11, 2014. The seedlings were planted in a single row in each bed, with a row spacing of $1 \mathrm{~m}$ and an interplant space of $0.5 \mathrm{~m}$ per row. Other cultivation practices were performed following the scheduled program of tomato crop. Harvest-ripe fruits were manually picked up and weighed twice a week, started on (20 April, 2013 and 23 April, 2014) and continued until the end of experiment and the last irrigation was on 29, 31 May in both 2013 and 2014, respectively, for crop growth period to 15 weeks.

At the beginning of harvesting stage, 60 days after transplanting, five plants were selected from each treatment. Vegetative growth traits, namely plant height, number of branches, leaf fresh weight, stem fresh weight, plant fresh weight ( leaf and stem fresh weight), leaf dry weight, stem dry weight and plant dry weight were measured. Dry weight samples (each about $100 \mathrm{~g}$ ) were determined by drying at $70^{\circ} \mathrm{C}$ until constant weight, using a forced-air oven at $70^{\circ} \mathrm{C}$ for $48-72 \mathrm{~h}$..

Fruit set (\%), fruit number and average fruit weight plant-1, fruit dimension (fruit length and diameter), fruit fresh weight, early fruit yield (the 
initial five harvests) and the total yield (all harvested fruits) were determined. In addition, the qualitative fruit traits in terms of fruit dry weight, vitamin C, titratable acidity, total soluble solids (TSS) and total sugar contents were assessed. Harvest-ripe fruits were manually picked and weighed twice a week, started on 5 May and continued until the end of experiment (30 may). Total fruit yield for each replicate was recorded to calculate the gross yield $\left(\mathrm{Mg} \mathrm{fed}^{-1}\right)$.

The qualitative traits were determined in a sample of 5 ripe fruits (from the third-fourth trusses) per treatment. Ripe fruits representing each sub-plot were picked for analysis of the fruit quality traits; dry weight $(\mathrm{g})$, total soluble solids (TSS, \%), vitamin C (mg $100 \mathrm{~g}-1 \mathrm{fw})$ and titratable acidity (TA, $\%$ ). An extract was obtained by blending and filtering flesh of each fruit sample. TSS (\%) was deliberated via a digital refractometer (PR-101 model, ATAGO, Japan). For determination TA, $10 \mathrm{~g}$ of extracted juice was taken and carefully mixed with $50 \mathrm{ml}$ of distilled water. The mixture was then titrated by $(0.1 \mathrm{~N}) \mathrm{NaOH}$ until a $\mathrm{pH}$ value reached 8.1. The volume of the sodium hydroxide added to the solution, was multiplied by a correction factor of 0.064 to estimate TA as the percentage of citric acid equivalents in the fruit juice (Turhan\&Seniz, 2009). Vitamin C (mg $100 \mathrm{~g}-1 \mathrm{fw}$, as ascorbic acid) was measured in tomato extract using 2,6 dichlorophenol-indophenol dye (Patane et al., 2011). TS content (\%) was also determined using standard methods of analysis (AOAC1995).

The estimation of consumptive use for irrigated crops is determined by the crop coefficient-reference evapotranspiration procedure. Reference evapotranspiration (ETo) is computed for a hypothetical reference crop according to the FAO paper No. 56 methodology (Allen et al., 1998) and is then multiplied by an empirical crop coefficient $(\mathrm{Kc})$ to produce an estimate of crop evapotranspiration (ETc), as in the following equation (1):

\section{$\mathrm{ETc}=\mathrm{Kc} \times \mathrm{ETO}$}

To calculate ETc and irrigation water requirement of tomato, the daily ETo values were firstly determined by the meteorological station and then were multiplied by crop coefficients and divided by the water application efficiency. Based on the area of the field and the discharge rate from the drippers (NETFIM $3.5 \mathrm{l} / \mathrm{h}$ ), the required water quantity per event and actual operation time required could be determined. Accordingly, the actual operation time required was then calculated. The irrigation system was turned on and off in control experiments manually in CIS plots. Furthermore, the irrigation water depths $(\mathrm{Dg})$ and cumulative depths added to the tomato crop under the two the (SIC) and (ICS) irrigation treatments were monitored by flow meters and were through the growing season. 


\section{Water use efficiency}

Irrigation water use efficiency (IWUE) $\mathrm{Kg} \mathrm{m}^{-3}$ was calculated according to Michael (1978) as follows:

$$
\operatorname{IWUE}=\left(\frac{\mathrm{Y}}{(\mathrm{Dg})_{\mathrm{t}}}\right), \mathbf{k g ~ m}^{-3}
$$

Where, $\mathrm{Y}$ is the total fresh yield $(\mathrm{kg})$, and $\mathrm{Dg} \mathrm{t}$ is the total amount of seasonally applied irrigation water $\left(\mathrm{m}^{3}\right)$.

\section{Experimental design and data analysis}

To evaluate the performance of three different scheduling techniques of the ET controllers Hunter-Pro C, SmartLine controllers and control treatment (manually) under two irrigation systems (surface drip and subsurface drip systems). The experimental layout was a split- plot system in randomized complete block design with 3 replications. Three different scheduling techniques of the ET controllers Hunter-Pro C, SmartLine controllers and control treatment system treatments were allocated to the main plots, two irrigation systems (surface drip and subsurface drip systems) treatments were arranged in the sub-plots. Analysis of variance (ANOVA) was used to determine any statistically significant differences (Steel \&Torrie, 1980). Computer program (SAS, 2008) was used to determine treatment effects for total vegetative growth, fruit yield components, fruit quality traits yield and IWUE. The means defferance of plaited treatments were compared with least significant difference (LSD) test at the $(p<0.05)$ level.

\section{RESULTS AND DISCUSSION}

\section{Irrigation management}

The systems with scheduling techniques (Hunter and SmartLine systems) were equipped with special options, including the addition of more or less water depending on the needs of the plants. These water quantities were monitored and recorded.

Cumulative average irrigation water depth for two seasons $(\mathrm{Dg}) \mathrm{c}$ was added by SmartLine and Hunter and Control system under subsurface irrigation systems are presented in Fig. (2). It shows that the weekly cumulative irrigation water added $[(\mathrm{Dg}) \mathrm{c}]$ throughout crop growing period for the three different scheduling techniques under SDI system. The depths of the water added for the SDI, DI and control system are 519.86, 568.45 and $690.68 \mathrm{~mm}$ (2182.66, 2387.49 and $\left.2900.86 \mathrm{~m}^{3} / \mathrm{fed} / \mathrm{season}\right)$, respectively. Thus, it is clear that there are significant differences among these three different scheduling techniques (Hunter-Pro C and SmartLine controllers and control treatment) under subsurface irrigation systems throughout the two growing season. This was to be expected, because the same controller device was used to schedule these replicates. 


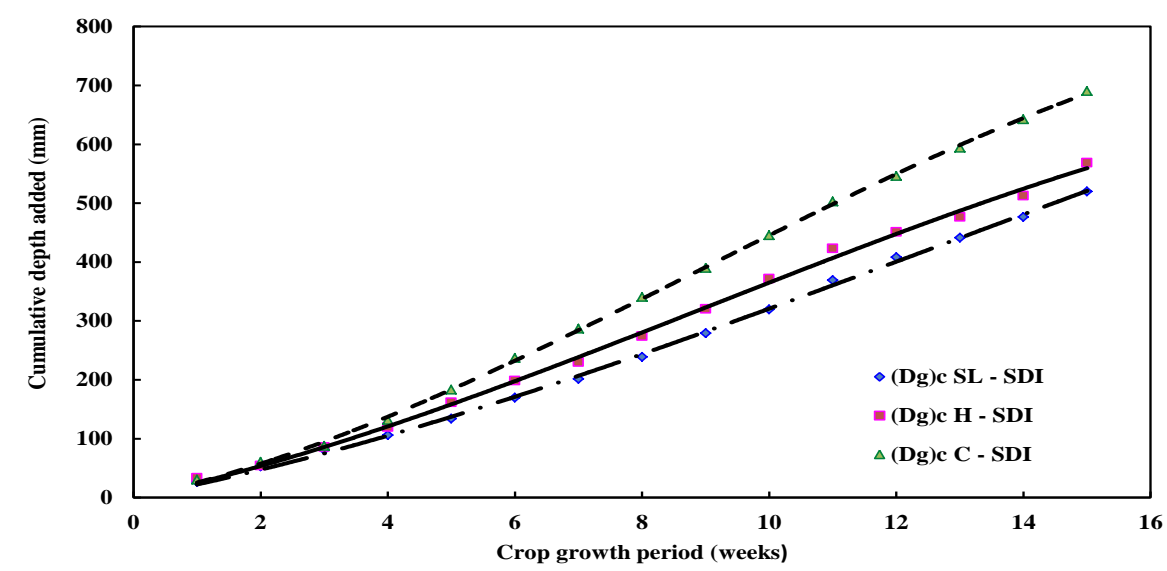

Fig.2. Comparison between the average depths of water added by subsurface drip irrigation systems using SmartLine and Hunter and Control system of the two growing seasons

The cumulative average irrigation water depth for the two seasons (Dg)c was added by SmartLine and Hunter and Control system under surface irrigation systems is presented in Fig. (3). It shows that the weekly cumulative irrigation water added $[(\mathrm{Dg}) \mathrm{c}]$ throughout the growing period for the three different scheduling techniques under SDI system. The depths of the water added for the SDI, DI and control system are $579.78,637.35$ and $751.77 \mathrm{~mm}$ (2435.08, 2676.87 and $3157.43 \mathrm{~m}^{3} / \mathrm{fed} /$ season), respectively. It is clear that there are significant differences among these three different scheduling techniques under subsurface irrigation systems throughout the two growing seasons. These averages are less than the average amount of irrigation water practiced by the framers in the area. Generally, the irrigation practice in Riyadh area is at least $720.2 \mathrm{~mm}$, which are $24 \%$ and $15 \%$ more than SDI and DI respectively. This result also shows that the DI system applied more water than SDI by $10.6 \%$. This was expected since the subsurface irrigation system is less susceptible to evaporation than drip irrigation. 


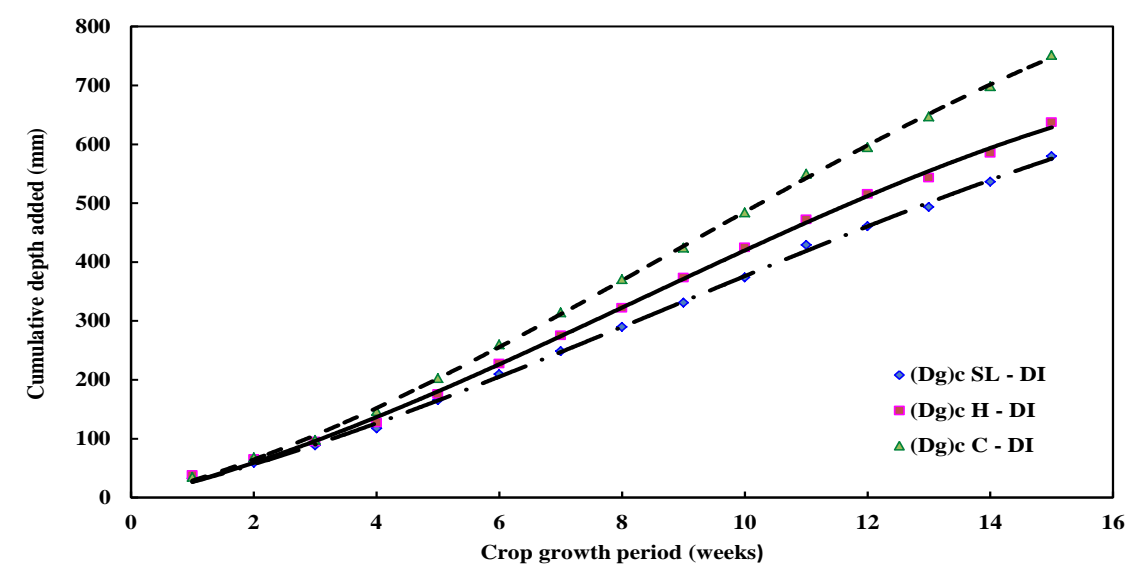

Fig. 3. Comparison between the average depths of water added by surface drip irrigation systems using SmartLine and Hunter and Control system of the two growing seasons

Comparison between depths of water added by SDI and DI systems under control treatment is shown in (Figs. 2 and 3). These figures points out that the values of the two treatments are close enough. This due to the fact that both systems are scheduled based on ETc calculations. These values are higher than the mentioned values in (Figs. 2 and 3) obtained by SmartLine and Hunter SDI and DI respectively. It means that the control treatment is higher by $24.76 \%$ and $22.88 \%$ than SmartLine and Hunter SDI and $\mathrm{DI}$ respectively. These findings are clear in the figs. (2 and 3) which describe the depths of water added by SDI and DI using SmartLine and Hunter and Control treatments.

It could be concluded from these results that the subsurface irrigation under SmartLine controller is applied less water as compared with other treatments. These data exhibited variations of more than $10 \%$ water added between the two systems. This might be due to the reduction of evaporation from the soil surface by using subsurface irrigation system and thus reduces the amount of irrigation water added.

These Figs. also show that depth of water applied (Dg) for all treatments are taking similar pattern, which means that increasing in initial growing weeks till reaching maximum during the middle period and then recess. Finally, these Figs. show that Dg was the lowest for SL - SDI and highest for C-DI treatment.

\section{Vegetative growth characteristics} Plant growth traits

Plant growth traits as plant height, number of branches, leaf fresh weight, stem fresh weight, plant fresh weight, leaf dry weight, stem dry weight and plant dry weight shows in are listed in Table (2) for the growing first season 2013 and Table (3) for the second season 2014. It is clear that the vegetative growth characteristics were significantly higher for the Hunter controller under the SDI system than for the other treatments; for example, 
plant height was found to be $75.12 \mathrm{~cm}$ as an average for the two seasons (Tables 2 and 3) with the Hunter controller under SDI but only $54.92 \mathrm{~cm}$ for the control treatment under SDI. Similarly, the number of branches, leaf fresh weight, stem fresh weight, plant fresh weight, leaf dry weight, stem dry weight, and plant dry weight were found to be $8.63,849.62,233.46,1038.12$, 89.76, 50.44, and $1140.20 \mathrm{~g}$, respectively, for the Hunter controller under SDI but $4.6,477.05,103.4,438.99,48.7,28.96$, and $71.64 \mathrm{~g}$ for the control treatment under DI.

Table (2): Growth variables of tomato plants as influenced by different scheduling techniques and irrigation systems treatments in 2013 growing season

\begin{tabular}{|c|c|c|c|c|c|c|c|c|c|}
\hline $\begin{array}{l}\text { Irrigation } \\
\text { systems }\end{array}$ & $\begin{array}{l}\text { Irrigation } \\
\text { methods }\end{array}$ & $\begin{array}{c}\text { Plant } \\
\text { height } \\
\text { (cm) }\end{array}$ & $\begin{array}{c}\text { No of } \\
\text { branches }\end{array}$ & \begin{tabular}{|} 
Leaf \\
fresh \\
weight \\
(g)
\end{tabular} & \begin{tabular}{|c|} 
Stem \\
fresh \\
weight \\
(g)
\end{tabular} & $\begin{array}{c}\text { Plant } \\
\text { fresh } \\
\text { weight } \\
\text { (g) }\end{array}$ & $\begin{array}{l}\text { Leaf dry } \\
\text { weight } \\
\text { (g) }\end{array}$ & \begin{tabular}{|c}
$\begin{array}{c}\text { Stem } \\
\text { dry } \\
\text { weight } \\
(\mathrm{g})\end{array}$ \\
\end{tabular} & \begin{tabular}{|c}
$\begin{array}{c}\text { Plant } \\
\text { dry } \\
\text { weight } \\
\text { (g) }\end{array}$ \\
\end{tabular} \\
\hline \multirow{3}{*}{$\begin{array}{l}\text { Subsurface } \\
\text { DI }\end{array}$} & $\begin{array}{l}\text { Hunter } \\
\text { Pro-C }\end{array}$ & & $\begin{array}{c}8.46 \\
\pm 0.17\end{array}$ & \begin{tabular}{|c|}
832.83 \\
\pm 226.64
\end{tabular} & \begin{tabular}{|l|}
228.82 \\
\pm 52.96 \\
\end{tabular} & \begin{tabular}{|l|}
1061.64 \\
\pm 279.59
\end{tabular} & & \begin{tabular}{|l|}
49.38 \\
\pm 5.48
\end{tabular} & $\begin{array}{l}137.39 \\
\pm 31.35\end{array}$ \\
\hline & $\begin{array}{l}\text { Weatherm } \\
\text { atic - SL }\end{array}$ & $\begin{array}{l}69.67 \\
\pm 8.70\end{array}$ & $\begin{array}{c}5.75 \\
\pm 1.44\end{array}$ & \begin{tabular}{|c|}
478.62 \\
\pm 210.23
\end{tabular} & \begin{tabular}{|}
153.21 \\
$\pm 24 . .81$
\end{tabular} & \begin{tabular}{|c|}
634.85 \\
\pm 234.18
\end{tabular} & $\begin{array}{c}64.39 \\
\pm 23.07\end{array}$ & $\begin{array}{l}29.03 \\
\pm 4.40\end{array}$ & $\begin{array}{r}93.42 \\
\pm 30.36\end{array}$ \\
\hline & control & $\begin{array}{r}53.7 \\
\pm 2.54\end{array}$ & $\begin{array}{c}5.52 \\
\pm 0.83\end{array}$ & $\begin{array}{l}720.26 \\
\pm 6084 \\
\end{array}$ & $\begin{array}{c}205.98 \\
\pm 6.50 \\
\end{array}$ & $\begin{array}{l}89 \\
\pm 2\end{array}$ & & $\begin{array}{l}37.84 \\
\pm 3.43\end{array}$ & $\begin{array}{l}117.68 \\
\pm 10.34 \\
\end{array}$ \\
\hline \multirow{3}{*}{$\begin{array}{l}\text { Surface } \\
\text { DI }\end{array}$} & $\begin{array}{l}\text { Hunter } \\
\text { Pro-C }\end{array}$ & $\begin{array}{l}71.93 \\
\pm 2.90 \\
\end{array}$ & $\begin{array}{r}7.08 \\
\pm 0.33 \\
\end{array}$ & $\begin{array}{r}552.82 \\
\pm 13.72 \\
\end{array}$ & \begin{tabular}{|c|}
176.7 \\
$5 \pm 9.13$ \\
\end{tabular} & $\begin{array}{r}729.57 \\
\pm 22.82 \\
\end{array}$ & & $\begin{array}{l}37.65 \\
\pm 4.52 \\
\end{array}$ & $\begin{array}{c}118.81 \\
\pm 7.75 \\
\end{array}$ \\
\hline & $\begin{array}{l}\text { Weatherm } \\
\text { atic - SL }\end{array}$ & \begin{tabular}{|l|}
66.36 \\
\pm 2.99 \\
\end{tabular} & $\begin{array}{c}5.30 \\
\pm 0.02 \\
\end{array}$ & \begin{tabular}{|c|}
265.31 \\
\pm 138.37 \\
\end{tabular} & $\begin{array}{c}135.92 \\
\pm 2.92 \\
\end{array}$ & $\begin{array}{l}504.71 \\
\pm 83.08 \\
\end{array}$ & $\begin{array}{l}7 \\
8 \\
\end{array}$ & $\begin{array}{l}27.78 \\
\pm 1.15 \\
\end{array}$ & $\begin{array}{l}81.95 \\
\pm 3.91 \\
\end{array}$ \\
\hline & control & $\begin{array}{l}48.89 \\
\pm 2.21 \\
\end{array}$ & $\begin{array}{c}4.5 \\
\pm 0.65 \\
\end{array}$ & \begin{tabular}{|c|}
468.8 \\
\pm 102.51 \\
\end{tabular} & $\begin{array}{l}101.5 \\
\pm 8.39 \\
\end{array}$ & $\begin{array}{c}430.99 \\
\pm 82.4\end{array}$ & $\begin{array}{r}47.9 \\
\pm 7.88 \\
\end{array}$ & $\begin{array}{l}28.42 \\
\pm 2.77 \\
\end{array}$ & $\begin{array}{l}70.38 \\
\pm 6.13 \\
\end{array}$ \\
\hline \multicolumn{10}{|c|}{ Mean Effect of irrigation systems, season 2013} \\
\hline \multicolumn{2}{|c|}{\begin{tabular}{|l} 
subsurface \\
surface
\end{tabular}} & $65.68 \mathrm{a}$ & $6.57 \mathrm{a}$ & $677.23 a$ & $196.00 \mathrm{a}$ & $865.34 a$ & $77.23 \mathrm{a}$ & $38.75 \mathrm{a}$ & $116.16 \mathrm{a}$ \\
\hline \multirow{2}{*}{\multicolumn{2}{|c|}{ surfe }} & $62.40 \mathrm{a}$ & $5.62 \mathrm{~b}$ & $428.98 b$ & $138.06 \mathrm{~b}$ & $555.09 \mathrm{~b}$ & $61.08 \mathrm{~b}$ & $31.28 \mathrm{~b}$ & $90.38 \mathrm{~b}$ \\
\hline & & \multicolumn{8}{|c|}{ Mean Effect of irrigation methods, season 2013} \\
\hline Hunter $\operatorname{Pr}$ & & $72.78 \mathrm{a}$ & $7.70 \mathrm{a}$ & $692.82 \mathrm{a}$ & $202.79 a$ & $895.61 a$ & $84.59 \mathrm{a}$ & $43.52 a$ & $128.10 \mathrm{a}$ \\
\hline \multirow{2}{*}{\multicolumn{2}{|c|}{\begin{tabular}{|l} 
Weathermatic - SL \\
control
\end{tabular}}} & $68.01 \mathrm{a}$ & $5.52 \mathrm{~b}$ & $371.97 \mathrm{~b}$ & $144.56 \mathrm{~b}$ & $569.78 \mathrm{~b}$ & & $33.12 \mathrm{~b}$ & $87.69 \mathrm{~b}$ \\
\hline & & $51.31 b$ & $5.001 \mathrm{~b}$ & $594.53 a$ & $153.74 \mathrm{~b}$ & $665.26 \mathrm{~b}$ & $63.59 \mathrm{~b}$ & $28.41 \mathrm{~b}$ & $94.03 b$ \\
\hline \multicolumn{10}{|c|}{ Interaction Effect of irrigation systems * irrigation methods, season 2013} \\
\hline $\mathrm{SD}(0.05)$ & & $64.04 \mathrm{~ns}$ & $6.10 \mathrm{~ns}$ & $553.11 \mathrm{~ns}$ & $167.03^{*}$ & $710.22 n s$ & $69.15 \mathrm{~ns}$ & $35.02 n s$ & $103.27 \mathrm{~ns}$ \\
\hline
\end{tabular}

Means in each column for each treatment followed by different letters are significantly different using revised LSD at 0.05 level

ns not significantly, * significantly

In general, Hunter Pro-C (Irrigation methods) and SDI (irrigation methods) significantly increased growth traits of tomato plants (Tables 2 and 3). Plant growth traits response to different irrigation methods technique was found to be linearly affected by increasing irrigation methods and irrigation systems, where no significant differences were detected between different irrigation methods technique and irrigation methods for the plant height (Tables 2 and 3).

The improvement of vegetative growth traits of tomato plants with irrigation method $(\mathrm{H}-\mathrm{SDI})$ may be attributed to the appropriate balance of 
moisture in plant, which creates good conditions for nutrients uptake, photosynthesis and metabolites translocation, which in final led to speed up the rate of vegetative growth (Ezzo et al. 2010).

Table (3): Growth variables of tomato plants as influenced by different scheduling techniques and irrigation systems treatments during growing season of 2014.

\begin{tabular}{|c|c|c|c|c|c|c|c|c|c|}
\hline $\begin{array}{l}\text { Irrigation } \\
\text { systems }\end{array}$ & $\begin{array}{l}\text { Irrigation } \\
\text { methods }\end{array}$ & $\begin{array}{c}\text { Plant } \\
\text { height } \\
\text { (cm) }\end{array}$ & $\begin{array}{c}\text { No of } \\
\text { branches }\end{array}$ & \begin{tabular}{|c|}
$\begin{array}{c}\text { Leaf } \\
\text { fresh } \\
\text { weight } \\
(\mathrm{g})\end{array}$ \\
\end{tabular} & $\begin{array}{l}\text { Stem } \\
\text { fresh } \\
\text { weight } \\
\text { (g) }\end{array}$ & \begin{tabular}{|c|}
$\begin{array}{c}\text { Plant } \\
\text { fresh } \\
\text { weight } \\
\text { (g) }\end{array}$ \\
\end{tabular} & \begin{tabular}{|c|}
$\begin{array}{c}\text { Leaf } \\
\text { dry } \\
\text { weight } \\
(\mathrm{g})\end{array}$ \\
\end{tabular} & \begin{tabular}{|c|}
$\begin{array}{c}\text { Stem } \\
\text { dry } \\
\text { weight } \\
(\mathrm{g})\end{array}$ \\
\end{tabular} & \begin{tabular}{|c|}
$\begin{array}{c}\text { Plant } \\
\text { dry } \\
\text { weight } \\
(\mathrm{g})\end{array}$ \\
\end{tabular} \\
\hline \multirow{3}{*}{ Subsurface } & $\begin{array}{c}\text { Hunter Pro- } \\
\text { C } \\
\end{array}$ & \begin{tabular}{|c|}
76.60 \\
\pm 13.70 \\
\end{tabular} & $\begin{array}{c}8.8 \\
\pm 0.21 \\
\end{array}$ & \begin{tabular}{|c|}
866.4 \\
\pm 226.3 \\
\end{tabular} & $\begin{array}{l}238.1 \\
\pm 52.5 \\
\end{array}$ & \begin{tabular}{|l|}
1104.6 \\
\pm 278.8 \\
\end{tabular} & $\begin{array}{c}91.5 \\
\pm 26.6 \\
\end{array}$ & $\begin{array}{r}51.5 \\
\pm 5.8 \\
\end{array}$ & $\begin{array}{r}143.0 \\
\pm 31.2 \\
\end{array}$ \\
\hline & $\begin{array}{c}\text { Weatherma } \\
\text { tic - SL }\end{array}$ & $\begin{array}{l}72.5 \\
\pm 8.6 \\
\end{array}$ & $\begin{array}{c}6.0 \\
\pm 1.46 \\
\end{array}$ & \begin{tabular}{|c|}
497.5 \\
\pm 215.8 \\
\end{tabular} & $\begin{array}{l}159.5 \\
\pm 24.9 \\
\end{array}$ & \begin{tabular}{|c|}
660.1 \\
\pm 239.7 \\
\end{tabular} & $\begin{array}{c}67.0 \\
\pm 23.6 \\
\end{array}$ & $\begin{array}{r}30.2 \\
\pm 7.6 \\
\end{array}$ & $\begin{array}{c}97.2 \\
\pm 31.0 \\
\end{array}$ \\
\hline & control & $\begin{array}{l}56.1 \\
\pm 1.5 \\
\end{array}$ & $\begin{array}{c}5.8 \\
\pm 0.77 \\
\end{array}$ & \begin{tabular}{|l|}
752.0 \\
\pm 50.9 \\
\end{tabular} & $\begin{array}{l}215.3 \\
\pm 10.4 \\
\end{array}$ & $\begin{array}{l}940.3 \\
\pm 40.8 \\
\end{array}$ & $\begin{array}{l}82.9 \\
\pm 3.0 \\
\end{array}$ & $\begin{array}{l}39.5 \\
\pm 3.6 \\
\end{array}$ & $\begin{array}{c}122.9 \\
\pm 8.8 \\
\end{array}$ \\
\hline \multirow{3}{*}{ Surface } & $\begin{array}{c}\text { Hunter Pro- } \\
\text { C }\end{array}$ & $\begin{array}{l}74.2 \\
\pm 3.1\end{array}$ & $\begin{array}{c}7.3 \\
\pm 0.31\end{array}$ & $\begin{array}{l}570.4 \\
\pm 11.7\end{array}$ & $\begin{array}{c}182.4 \\
\pm 8.6\end{array}$ & $\begin{array}{l}752.8 \\
\pm 20.3\end{array}$ & $\begin{array}{l}83.7 \\
\pm 3.0\end{array}$ & $\begin{array}{l}38.8 \\
\pm 4.5\end{array}$ & $\begin{array}{c}122.6 \\
\pm 7.5\end{array}$ \\
\hline & $\begin{array}{c}\text { Weatherma } \\
\text { tic - SL }\end{array}$ & $\begin{array}{l}69.0 \\
\pm 3.1\end{array}$ & $\begin{array}{c}5.5 \\
\pm 0.03\end{array}$ & \begin{tabular}{|c|}
276.4 \\
\pm 144.8 \\
\end{tabular} & $\begin{array}{l}141.4 \\
\pm 2.7\end{array}$ & $\begin{array}{l}524.8 \\
\pm 84.9\end{array}$ & $\begin{array}{l}56.3 \\
\pm 2.9\end{array}$ & $\begin{array}{l}28.9 \\
\pm 1.2\end{array}$ & $\begin{array}{l}85.2 \\
\pm 3.9\end{array}$ \\
\hline & control & $\begin{array}{l}50.7 \\
\pm 1.5\end{array}$ & $\begin{array}{c}4.7 \\
\pm 0.68\end{array}$ & \begin{tabular}{|c|}
485.3 \\
\pm 101.9 \\
\end{tabular} & $\begin{array}{c}105.3 \\
\pm 9.7\end{array}$ & $\begin{array}{l}447.0 \\
\pm 85.6\end{array}$ & $\begin{array}{l}49.5 \\
\pm 6.5\end{array}$ & $\begin{array}{l}29.5 \\
\pm 3.6\end{array}$ & $\begin{array}{l}72.9 \\
\pm 3.0\end{array}$ \\
\hline \multicolumn{10}{|c|}{ Mean Effect of irrigation systems, season 2014} \\
\hline subsu & & 6 & & $705.32 \mathrm{a}$ & $204.30 \mathrm{a}$ & $901.66 \mathrm{a}$ & $80.45 a$ & $40.40 \mathrm{a}$ & $121.01 \mathrm{a}$ \\
\hline Surfa & & $64.65 a$ & $5.83 b$ & $444.04 \mathrm{~b}$ & $143.02 b$ & $574.86 \mathrm{~b}$ & $63.20 \mathrm{~b}$ & $32.42 b$ & $93.56 \mathrm{~b}$ \\
\hline \multicolumn{10}{|c|}{ Mean Effect of irrigation methods, season 2014} \\
\hline Hunte & 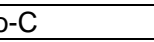 & $75.41 \mathrm{a}$ & & $718.43 a$ & $210.24 a$ & $928.67 a$ & $87.64 a$ & $45.15 a$ & $132.79 a$ \\
\hline Weatherm & atic - SL & 70.78 & $5.75 b$ & $386.94 \mathrm{~b}$ & $150.42 \mathrm{~b}$ & $592.46 \mathrm{~b}$ & $61.65 \mathrm{~b}$ & $29.56 \mathrm{~b}$ & $91.21 \mathrm{~b}$ \\
\hline ontrol & & $53.41 \mathrm{~b}$ & $5.21 \mathrm{~b}$ & $618.67 a$ & $160.33 \mathrm{~b}$ & $693.67 \mathrm{~b}$ & $66.20 \mathrm{~b}$ & $34.53 \mathrm{~b}$ & $97.87 \mathrm{~b}$ \\
\hline \multicolumn{10}{|c|}{ Interaction Effect of irrigation systems * irrigation methods, season 2014} \\
\hline $\operatorname{LSD}(0.05$ & & $\begin{array}{c}66.53 \\
\mathrm{~ns}\end{array}$ & $\begin{array}{c}6.34 \\
\mathrm{~ns}\end{array}$ & \begin{tabular}{|c|}
$\begin{array}{c}574.68 \\
n s\end{array}$ \\
\end{tabular} & $173.66^{*}$ & $\begin{array}{c}738.26 \\
n s\end{array}$ & $\begin{array}{c}71.83 \\
\mathrm{~ns}\end{array}$ & $\begin{array}{c}36.41 \\
\mathrm{~ns}\end{array}$ & $\begin{array}{c}107.29 \\
\text { ns }\end{array}$ \\
\hline
\end{tabular}

Means in each column for each treatment followed by different letters are significantly different using revised LSD at $\mathbf{0 . 0 5}$ level ns not significantly, ${ }^{*}$ significantly

\section{Fruit qualitative}

Fruit quality traits as an average fruit weight $(\mathrm{g})$, number of fruit per plant, fruit length $(\mathrm{cm})$, fruit diameter $(\mathrm{cm})$, dry matter $(\%)$,total soluble solid (TSS \%), vitamin C (g/100 g FW) and total acidity (TA \%), also total yield $(\mathrm{Mg} / \mathrm{fed})$ and IWUE $\left(\mathrm{Kg} \mathrm{m}^{-3}\right)$ were summarized and listed in Tables (4 and 5).

It demonstrates that, the Hunter controller under SDI produced significantly greater increases in yield characteristics (average fruit weight $\mathrm{g}$, fruit length $\mathrm{cm}$, fruit diameter $\mathrm{cm}$, yield $\mathrm{Mg} / \mathrm{fed}$ and IWUE per plant) than the other treatments for the two season 2013 -2014.

From Tables (4 and 5), It is clear that the Hunter controller under the SDI system produced the highest values of fruit length $(5.8 \mathrm{~cm}$ as average two seasons) and fruit diameter traits, followed by the Hunter controller under DI $(5.5 \mathrm{~cm}$ as an average for the two seasons), whereas the lowest fruit length and diameter were produced by the control experiment under DI (3.8 $\mathrm{cm}$ as an average for the two seasons). Conversely, these results demonstrate that the highest values of dry matter (\%), total soluble solid (\%), 
vitamin C ( $\mathrm{g} / 100 \mathrm{~g} \mathrm{FW})$, and total acidity (\%) were achieved by the SmartLine controller under SDI, with the lowest values of these four by traits were achieved by the control under DI.

The highest values of fruit set, fruit number, fruit dimension (length and diameter), and total fruit yield were obtained when tomato plants irrigated with Hunter controller under SDI. This irrigation methods ( $\mathrm{H}-\mathrm{SDI})$ promoted the vegetative growth of tomato plants (Tables 4 and 5); which in turn reflected. Their effect on fruit set, fruit number, fruit dimension, and total fruit yield. This result can be attributed to the role of water as a vital component for growth and development of tomato fruits, since the water forms $94-95 \%$ of the total fruit fresh weight (Turhan and Seniz 2009). These results are substantiated by the findings of high yield of quality tomato fruits can be obtained under the conditions of optimal soil moisture at ripening greatly affect tomato fruit quality. These results are in agreement with those of (Aksic et al. 2011), (Zotarelli,et al. 2009). The explanation of shortage of irrigation water results in decreased fruit yield and quality.

In general, the results of analysis of variance for tomato vegetative growth the data analysis indicate that, yield and fruit quality characters as affected by irrigation systems showed that there were significant effects for irrigation systems on all studied traits. The results of main effect showed that Hunter treatment significantly increase most studied traits as compared with the two systems of irrigation. Also the results clarified that subsurface methods significantly increase all vegetative growth traits as compared with surface methods. The comparison between SmartLine, SL-1600 (SL) and Hunter Pro-C $(\mathrm{H})$ systems using subsurface or surface methods (interaction,) showed that the treatment combination Hunter Pro-C $(\mathrm{H})$ systems with subsurface irrigation methods had the heights values for all traits.

Irrigation water use efficiency

Table (6) compares IWUE during the two growing seasons for the two smart controller irrigation systems and different water-saving treatments, as compared with the results achieved by the typical local practices for tomato cultivation. It is clear that the highest IWUE was achieved using the Hunter controller under the SDI treatment. The tomato yield in the case of Hunter controller under SDI treatment, were $37.80(\mathrm{~kg} / \mathrm{fed})$ as an average for the two seasons. Moreover, the amounts of applied irrigation water were $2387.52 \mathrm{~m}^{3} / \mathrm{fed}$ as an average for the seasons of growing (Table 6). In contrast, the minimum amounts of irrigation water used were $2182.64 \mathrm{~m}^{3} / \mathrm{fed}$ in case of smartLine controller under SDI, while the largest amount of applied irrigation was $3157.42 \mathrm{~m}^{-3}$ fed in the control under DI treatment, respectively.

The results in Table 6 demonstrate differences in the amount of water applied to the tomato crop and the resulting yield for the three irrigation scheduling methods. The data were normalized to produce a tomato crop yield per $\mathrm{mm}$ water depth applied, providing values of 66.50 (48.91), 62.74 (47.75), and $35.54(28.21) \mathrm{kg} / \mathrm{mm}$ for the Hunter, SmartLine, and control 
systems, respectively, under SDI and DI. Conversely, the average water depth applied by local farmers in the same region of Riyadh during the previous 10 years for tomato crop production under surface DI was 16.15 $\mathrm{kg} / \mathrm{mm}$.

In general, the results of the data analysis indicate that, the irrigation scheduling methods investigated, the Hunter Pro-C system saves most water and produces the greatest yield with the highest IWUE (Table 6). However, the SmartLine system applied less irrigation water than the Hunter system. The results also indicate that the SDI system produced a higher yield and IWUE than the surface drip system. Therefore, it can be concluded that the irrigation water was used most effectively with the Hunter controller under the SDI treatment.

Table (4). Fruit qualitative of tomato plants as influenced by different scheduling techniques and irrigation systems treatments in 2013 growing season

\begin{tabular}{|c|c|c|c|c|c|c|c|c|c|c|c|}
\hline $\begin{array}{c}\text { Irrigation } \\
\text { systems }\end{array}$ & $\begin{array}{l}\text { Irrigation } \\
\text { methods }\end{array}$ & $\begin{array}{c}\text { Average } \\
\text { fruit } \\
\text { weight } \\
\text { (g) }\end{array}$ & $\begin{array}{c}\text { No. fruit } \\
\text { per } \\
\text { plant }\end{array}$ & $\begin{array}{c}\text { Fruit } \\
\text { length } \\
(\mathrm{cm})\end{array}$ & $\begin{array}{c}\text { Fruit } \\
\text { diameter } \\
\text { (cm) }\end{array}$ & $\begin{array}{c}\text { Dry } \\
\text { matter } \\
(\%)\end{array}$ & \begin{tabular}{|c|} 
Total \\
soluble \\
solid \\
(TSS \\
$\%)$
\end{tabular} & $\begin{array}{c}\text { Vitamin } \\
\text { C } \\
(g / 100 \\
\text { g FW) }\end{array}$ & $\begin{array}{l}\text { Total } \\
\text { acidity } \\
\text { (TA \%) }\end{array}$ & $\begin{array}{c}\text { yield } \\
\mathrm{Mg} / \mathrm{fed}\end{array}$ & $\begin{array}{l}\text { IWUE } \\
\text { kgm }^{-3}\end{array}$ \\
\hline \multirow{3}{*}{ Subsurface } & \begin{tabular}{|c|} 
Hunter Pro- \\
C \\
\end{tabular} & $\begin{array}{l}146.35 \\
\pm 6.01 \\
\end{array}$ & & \pm 0.64 & \pm & \begin{tabular}{|c|}
4.89 \\
\pm 0.18 \\
\end{tabular} & $\begin{array}{r}5.94 \\
\pm 0.18 \\
\end{array}$ & $\begin{array}{l}51 \\
11 \\
\end{array}$ & $\begin{array}{l}0.57 \\
0.01 \\
0.01\end{array}$ & $\begin{array}{l}37.19 \\
\pm 6.01 \\
\end{array}$ & \\
\hline & $\begin{array}{c}\text { Weathermati } \\
\text { c-SL }\end{array}$ & $\begin{array}{l}126.20 \\
\pm 10.25\end{array}$ & & $\begin{array}{c}5.01 \\
\pm 0.24\end{array}$ & & \begin{tabular}{|c|}
6.07 \\
\pm 0.46 \\
\end{tabular} & $\begin{array}{r}6.40 \\
\pm 0.29\end{array}$ & $\begin{array}{l}26.86 \\
\pm 2.11\end{array}$ & & & \\
\hline & cont & $\begin{array}{l}98.77 \\
\pm 2.22 \\
\end{array}$ & & $\begin{array}{c}4.34 \\
\pm 0.56 \\
\end{array}$ & $\begin{array}{c}4.06 \\
\pm 0.44 \\
\end{array}$ & \begin{tabular}{|c|}
3.80 \\
\pm 0.43 \\
\end{tabular} & $\begin{array}{r}3.52 \\
\pm 0.08 \\
\end{array}$ & $\begin{array}{l}16.48 \\
\pm 1.37 \\
\end{array}$ & & & $\begin{array}{r}8.42 \\
\pm 0.17 \\
\end{array}$ \\
\hline \multirow{3}{*}{ Surface } & \begin{tabular}{|c|} 
Hunter Pro- \\
C \\
\end{tabular} & $\begin{array}{l}135.32 \\
\pm 4.13 \\
\end{array}$ & $\begin{array}{l}21.51 \\
\pm 3.27 \\
\end{array}$ & $\begin{array}{c}5.40 \\
\pm 0.12 \\
\end{array}$ & $\begin{array}{r}5.46 \\
\pm 0.11 \\
\end{array}$ & \begin{tabular}{|c|}
5.43 \\
\pm 0.06 \\
\end{tabular} & $\begin{array}{r}6.40 \\
\pm 0.12 \\
\end{array}$ & $\begin{array}{l}27.48 \\
\pm 1.15 \\
\end{array}$ & $\begin{array}{c}0.59 \\
\pm 0.01 \\
\end{array}$ & & \begin{tabular}{|l|}
11.56 \\
\pm 0.06 \\
\end{tabular} \\
\hline & $\begin{array}{c}\text { Weathermati } \\
\text { C-SL }\end{array}$ & $\begin{array}{c}118.22 \\
\pm 3.25 \\
\end{array}$ & & $\begin{array}{c}5.06 \\
\pm 0.07 \\
\end{array}$ & $\begin{array}{c}4.96 \\
\pm 0.16 \\
\end{array}$ & \begin{tabular}{|c|}
6.43 \\
\pm 0.05 \\
\end{tabular} & $\begin{array}{c}6.57 \\
\pm 0.04 \\
\end{array}$ & $\begin{array}{l}26.92 \\
\pm 0.53 \\
\end{array}$ & $\begin{array}{c}0.61 \\
\pm 0.01 \\
\end{array}$ & & \begin{tabular}{|l|}
11.36 \\
\pm 0.07 \\
\end{tabular} \\
\hline & con & $\begin{array}{l}89.25 \\
\pm 7.44 \\
\end{array}$ & $\begin{array}{l}24.21 \\
\pm 1.56 \\
\end{array}$ & $\begin{array}{c}3.72 \\
\pm 0.14 \\
\end{array}$ & $\begin{array}{r}3.7 \\
\pm 0.59 \\
\end{array}$ & \begin{tabular}{|c|}
3.57 \\
\pm 0.35 \\
\end{tabular} & $\begin{array}{r}3.32 \\
\pm 0.32 \\
\end{array}$ & $\begin{array}{l}14.98 \\
\pm 0.78 \\
\end{array}$ & $\begin{array}{c}0.35 \\
\pm 0.05 \\
\end{array}$ & & $\begin{array}{r}6.62 \\
\pm 0.30 \\
\end{array}$ \\
\hline \multicolumn{12}{|c|}{ Mean Effect of irrigation systems, season 2013} \\
\hline subs & & $123.77 a$ & $26.32 a$ & $5.01 \mathrm{a}$ & $4.96 a$ & $5.14 a$ & $5.29 a$ & $22.62 a$ & $0.52 \mathrm{a}$ & & $13.09 a$ \\
\hline & & $114.26 \mathrm{~b}$ & $20.71 b$ & $4.72 a$ & $4.71 \mathrm{a}$ & $4.92 b$ & $5.43 a$ & $23.12 a$ & $0.51 \mathrm{a}$ & $26.06 \mathrm{a}$ & $9.85 b$ \\
\hline \multicolumn{12}{|c|}{ Mean Effect of irrigation methods, season 2013} \\
\hline Hunt & & $140.84 a$ & $25.59 a$ & $5.54 a$ & $5.61 \mathrm{a}$ & $5.16 \mathrm{~b}$ & $6.17 \mathrm{~b}$ & $25.99 a$ & $0.58 \mathrm{~b}$ & $33.84 \mathrm{a}$ & $3.73 a$ \\
\hline Weat & - SL & b & $20.97 a$ & 5 & 5 & $6.25 a$ & a & a & a & $\begin{array}{c}29.56 a \\
b\end{array}$ & $13.16 \mathrm{~b}$ \\
\hline Control & & $94.01 \mathrm{c}$ & $23.98 \mathrm{a}$ & $4.03 \mathrm{c}$ & $3.88 \mathrm{c}$ & $3.69 c$ & $3.42 \mathrm{c}$ & $15.73 b$ & $0.37 \mathrm{~b}$ & $22.25 \mathrm{~b}$ & $7.52 \mathrm{c}$ \\
\hline \multicolumn{12}{|c|}{ Interaction Effect of irrigation systems * irrigation methods, season 2013} \\
\hline $\operatorname{LSD}(0.0$ & & $\begin{array}{c}119.02 \\
\mathrm{~ns}\end{array}$ & $\begin{array}{c}23.51 \\
n s\end{array}$ & $\begin{array}{c}4.87 \\
\text { ns }\end{array}$ & $\begin{array}{c}4.83 \\
\mathrm{~ns}\end{array}$ & $\begin{array}{c}5.03 \\
n s\end{array}$ & o & 22.81 & $\begin{array}{c}0.52 \\
\mathrm{~ns}\end{array}$ & $\begin{array}{c}28.55 \\
n s\end{array}$ & $.47^{*}$ \\
\hline
\end{tabular}

Means in each column for each treatment followed by different letters are significantly different using revised LSD at 0.05 level ns not significantly, * significantly 
Table (5). Fruit qualitative of tomato plants as influenced by different scheduling techniques and irrigation systems treatments in 2014 growing season

\begin{tabular}{|c|c|c|c|c|c|c|c|c|c|c|c|}
\hline \multirow{4}{*}{\begin{tabular}{|l|}
$\begin{array}{c}\text { Irrigation } \\
\text { systems }\end{array}$ \\
Subsurface
\end{tabular}} & \multirow{2}{*}{\begin{tabular}{|c|}
$\begin{array}{c}\text { Irrigation } \\
\text { methods }\end{array}$ \\
$\begin{array}{c}\text { Hunter Pro- } \\
\text { C }\end{array}$ \\
\end{tabular}} & $\begin{array}{c}\text { Average } \\
\text { fruit } \\
\text { weight } \\
\text { (g) }\end{array}$ & $\begin{array}{c}\text { No. } \\
\text { fruit } \\
\text { per } \\
\text { plant }\end{array}$ & $\begin{array}{c}\text { Fruit } \\
\text { length } \\
(\mathrm{cm})\end{array}$ & $\begin{array}{c}\text { Fruit } \\
\text { diamete } \\
\text { r (cm) }\end{array}$ & $\begin{array}{c}\text { Dry } \\
\text { matter } \\
(\%)\end{array}$ & \begin{tabular}{|c} 
Total \\
solubl \\
e solid \\
(TSS \\
$\%$ )
\end{tabular} & $\begin{array}{c}\text { Vitamin } \\
\text { C (g/100 } \\
\text { g FW) }\end{array}$ & $\begin{array}{c}\text { Total } \\
\text { acidity } \\
\text { (TA \%) }\end{array}$ & $\underset{\text { Mg/fedd }}{\text { yield }}$ & $\begin{array}{l}\text { IWUE } \\
\text { kgm }^{-3}\end{array}$ \\
\hline & & $\begin{array}{l}152.5 \\
\pm 4.6\end{array}$ & & $\begin{array}{c}5.9 \\
\pm 0.6\end{array}$ & $\begin{array}{c}6.0 \\
\pm 0.6\end{array}$ & $\begin{array}{c}5.1 \\
\pm 0.2\end{array}$ & $\begin{array}{c}6.2 \\
\pm 0.2 \\
\end{array}$ & $\begin{array}{l}25.5 \\
\pm 1.3 \\
\end{array}$ & $\begin{array}{c}0.6 \\
\pm 0.1 \\
\end{array}$ & $\begin{array}{l}38.41 \\
\pm 6.27 \\
\end{array}$ & \\
\hline & $\begin{array}{c}\text { Weathermat } \\
\text { ic - SL }\end{array}$ & $\begin{array}{l}131.4 \\
\pm 9.7\end{array}$ & $\begin{array}{l}26.6 \\
\pm 7.1\end{array}$ & $\begin{array}{c}5.2 \\
\pm 0.2\end{array}$ & $\begin{array}{c}5.3 \\
\pm 0.4\end{array}$ & $\begin{array}{c}6.3 \\
\pm 0.5\end{array}$ & $\begin{array}{c}6.7 \\
\pm 0.3\end{array}$ & $\begin{array}{r}28.0 \\
\pm 2.4\end{array}$ & $\begin{array}{c}0.6 \\
\pm 0.5\end{array}$ & $\begin{array}{r}33.19 \\
\pm 8.96\end{array}$ & $\begin{array}{r}14.87 \\
\pm 0.23\end{array}$ \\
\hline & control & $\begin{array}{l}103.3 \\
\pm 4.3 \\
\end{array}$ & $\begin{array}{l}24.8 \\
\pm 1.0 \\
\end{array}$ & $\begin{array}{c}4.5 \\
\pm 0.5\end{array}$ & $\begin{array}{c}4.2 \\
\pm 0.4\end{array}$ & $\begin{array}{c}4.0 \\
\pm 0.5\end{array}$ & $\begin{array}{c}3.7 \\
\pm 0.1\end{array}$ & $\begin{array}{r}17.2 \\
\pm 1.1\end{array}$ & $\begin{array}{c}0.4 \\
\pm 0.6\end{array}$ & $\begin{array}{l}25.19 \\
\pm 3.44\end{array}$ & $\begin{array}{c}8.49 \\
\pm 0.16\end{array}$ \\
\hline & \begin{tabular}{|c|} 
Hunter Pro- \\
C
\end{tabular} & $\begin{array}{l}139.6 \\
\pm 3.7\end{array}$ & $\begin{array}{r}22.2 \\
\pm 3.5\end{array}$ & $\begin{array}{c}5.6 \\
\pm 0.1\end{array}$ & $\begin{array}{c}5.6 \\
\pm 0.1\end{array}$ & $\begin{array}{c}5.6 \\
\pm 0.1\end{array}$ & $\begin{array}{c}6.6 \\
\pm 0.1\end{array}$ & $\begin{array}{l}28.4 \\
\pm 1.3\end{array}$ & $\begin{array}{c}0.6 \\
\pm 0.01\end{array}$ & $\begin{array}{l}31.88 \\
\pm 3.50\end{array}$ & $\begin{array}{l}11.71 \\
\pm 0.25\end{array}$ \\
\hline Surface & $\begin{array}{c}\text { Weathermat } \\
\text { ic - SL }\end{array}$ & $\begin{array}{l}123.0 \\
\pm 3.9\end{array}$ & $\begin{array}{l}17.1 \\
\pm 5.2\end{array}$ & $\begin{array}{c}5.3 \\
\pm 0.1\end{array}$ & $\begin{array}{c}5.2 \\
\pm 0.2\end{array}$ & $\begin{array}{c}6.7 \\
\pm 0.1\end{array}$ & $\begin{array}{c}6.8 \\
\pm 0.1\end{array}$ & $\begin{array}{l}28.0 \\
\pm 0.6\end{array}$ & $\begin{array}{c}0.6 \\
\pm 0.02\end{array}$ & $\begin{array}{l}28.27 \\
\pm 8.76\end{array}$ & $\begin{array}{l}11.38 \\
\pm 0.10\end{array}$ \\
\hline & control & $\begin{array}{l}-92.5 \\
\pm 6.4\end{array}$ & $\begin{array}{l}25.1 \\
\pm 0.5\end{array}$ & $\begin{array}{r}3.9 \\
\pm 0.1 \\
\end{array}$ & $\begin{array}{c}3.8 \\
\pm 0.6 \\
\end{array}$ & $\begin{array}{c}3.7 \\
\pm 0.4\end{array}$ & $\begin{array}{c}3.4 \\
\pm 0.2 \\
\end{array}$ & $\begin{array}{l}15.5 \\
\pm 1.0 \\
\end{array}$ & $\begin{array}{c}0.4 \\
\pm 0.04\end{array}$ & $\begin{array}{l}21.82 \\
\pm 7.23 \\
\end{array}$ & $\begin{array}{c}6.73 \\
\pm 0.13\end{array}$ \\
\hline \multicolumn{12}{|c|}{ Mean Effect of irrigation systems, season 2014} \\
\hline Subs & & $129.03 a$ & $27.47 \mathrm{a}$ & \begin{tabular}{|l|l|l}
$5.22 \mathrm{a}$ & 5 \\
\end{tabular} & $5.17 a$ & $5.13 a$ & $5.51 a$ & $23.58 \mathrm{a}$ & $0.54 a$ & $32.26 \mathrm{a}$ & $13.04 \mathrm{a}$ \\
\hline Surfa & & $118.37 \mathrm{~b}$ & $21.46 \mathrm{~b}$ & $4.90 \mathrm{a}$ & $4.88 \mathrm{a}$ & $5.33 a$ & $5.63 a$ & $23.97 a$ & $0.53 a$ & $27.32 \mathrm{a}$ & $9.94 \mathrm{~b}$ \\
\hline \multicolumn{12}{|c|}{ Mean Effect of irrigation methods, season 2014} \\
\hline Hunt & & $146.05 a$ & $26.59 a$ & $5.75 \mathrm{a}$ & $5.81 a$ & $5.35 \mathrm{~b}$ & $6.40 \mathrm{~b}$ & $26.95 a$ & $0.61 a$ & $35.15 \mathrm{a}$ & $13.73 a$ \\
\hline Wea & ic - SL & $97.89 b$ & $21.84 a$ & $5.24 b$ & $5.22 b$ & $6.51 \mathrm{a}$ & $6.75 a$ & $27.99 a$ & $0.62 a$ & $30.73 a b$ & $13.13 b$ \\
\hline Control & & 127.18b & $24.95 a$ & $4.19 c$ & $4.04 c$ & $3.84 \mathrm{c}$ & $3.56 c$ & $16.37 \mathrm{~b}$ & $0.39 b$ & $23.51 \mathrm{ab}$ & $7.61 \mathrm{c}$ \\
\hline \multicolumn{12}{|c|}{ Interaction Effect of irrigation systems * irrigation methods , season 2014} \\
\hline $\operatorname{LSD}(0.05)$ & & $123.70 \mathrm{~ns}$ & $24.46 n s$ & \begin{tabular}{|l|l|l|l}
$5.06 \mathrm{~ns}$ & 5 \\
\end{tabular} & $5.02 n s$ & $5.23 n s$ & $5.57^{*}$ & $23.77^{*}$ & $0.54 n s$ & $29.79 \mathrm{~ns}$ & $11.49 a b$ \\
\hline \multicolumn{12}{|c|}{$\begin{array}{l}\text { Means in each column for each treatment followed by different letters are significantly } \\
\text { different using revised LSD at } 0.05 \text { level } \\
\text { ns not significantly, * significantly }\end{array}$} \\
\hline \multicolumn{12}{|c|}{$\begin{array}{l}\text { Table (6).Comparison between average IWUE of the two smart controller } \\
\text { irrigation systems and saving water with different treatments } \\
\text { and farmers treatments for the two growing }\end{array}$} \\
\hline \multirow{2}{*}{\multicolumn{2}{|c|}{$\begin{array}{c}\text { Main } \\
\text { treatments }\end{array}$}} & \multirow{2}{*}{\multicolumn{2}{|c|}{\begin{tabular}{|c|} 
Sub \\
Treatments,
\end{tabular}}} & \multicolumn{4}{|c|}{ Water added } & \multirow{2}{*}{\multicolumn{2}{|c|}{$\begin{array}{l}\text { Total yield } \\
\text { (Mg/fed) }\end{array}$}} & \multirow{2}{*}{\multicolumn{2}{|c|}{$\begin{array}{l}\text { IWUE } \\
\left(\mathrm{kg} \mathrm{m}^{-3}\right)\end{array}$}} \\
\hline & & & & Mm, & & $\mathrm{m}^{3} / \mathrm{fe}$ & & & & & \\
\hline & & & & & Sea & isolis 2 & & & & & \\
\hline \multirow{2}{*}{\multicolumn{2}{|c|}{\begin{tabular}{|l|} 
Weathermatic - SL \\
Hunter Pro-C
\end{tabular}}} & \multicolumn{2}{|c|}{ Subsurface } & 508.75 & \multicolumn{3}{|c|}{2136.76} & 32.02 & & & \\
\hline & & Subs & surface & 556.20 & & 2635.26 & & 37.19 & & & \\
\hline control & & Subs & urface & 675.16 & & 2835.67 & & 23.90 & & & \\
\hline Weatherm & natic - SL & & Prip & 568.65 & & 2388 & & 27.10 & & 11 & \\
\hline Hunter Prc & & & Prip & 627.44 & & 2635.26 & & 30.48 & & & \\
\hline control & & & Drip & 734.64 & & 3085.50 & & 20.60 & & 6. & \\
\hline & & & & & & ( & 14 & & & & \\
\hline Weatherm & natic - SL & Subs & urface & 530.60 & & 2228.5 & & 33.18 & & 14.8 & \\
\hline Hunter Prc & $\mathrm{O}-\mathrm{C}$ & Subs & surface & 580.71 & & 2438.98 & & 38.41 & & 15.7 & \\
\hline control & & Subs & urface & 706.18 & & 2965.96 & & 25.19 & & 8.49 & \\
\hline Weatherm & natic - SL & & Prip & 590.94 & & 2481.95 & & 28.27 & & 11.3 & \\
\hline Hunter Prc & $\mathrm{O}-\mathrm{C}$ & & rip & 647.60 & & 2719.9 & & 31.89 & & 11.7 & \\
\hline control & & & rip & 768.89 & & 3229.34 & & 21.82 & & 6.73 & \\
\hline & Farm & & & 1035 & & 4373 & & 16.72 & & 3.85 & \\
\hline
\end{tabular}


The highest total yield was $37.80 \mathrm{~kg} / \mathrm{fed}$ (Table 6 as an average two seasons) obtained by using Hunter Pro- $\mathrm{C}$ as irrigation method, meanwhile, the lowest total yield was $21.21 \mathrm{~kg} / \mathrm{fed}$ (Table 6 as an average for the two seasons) obtained by using control method in irrigation tomatoes. It is evident that IWUE decreased with increasing applied irrigation level. Irrigation water use efficiencies ranged from 14.3 to $25.8 \mathrm{~kg} \mathrm{~m}^{-3}$ depending on the treatments and experimental years (Table 6). Considering the averaged values, the maximum IWUE of $15.82 \mathrm{~kg} \mathrm{~m}^{-3}$ was obtained from $\mathrm{H}$ - SDI. As a result, IWUEs of the treatments in which the basis was Hunter Pro-C $(H)$ systems using subsurface were significantly high compared with another different scheduling techniques (Fig. 4). Furthermore, IWUEs differ considerable among the treatments and generally tends to increase with an adequate in irrigation (Zotarelli et al., 2009). The higher yield obtains also the higher IWUE. On the other hand, smart irrigation techniques are available for increasing the efficiency of water use in irrigated agriculture. Reducing water application irrigation is typically minimized to achieve improved crop water use. These results are in agreement with those of Al-Ghobari and Fawzi (2011), Davis and Dukes (2012), Al-Ghobari et al. (2013) and Mohammad et al. (2013). The explanation of the effect of increasing total yield by using Hunter Pro-C as irrigation method compare with the other two methods was performedand this is due to the fact that $\mathrm{H}$-SDI can certainly enhance water absorbing capacity of the roots. Moreover, it helps in the maintenance of optimum moisture around root zone.
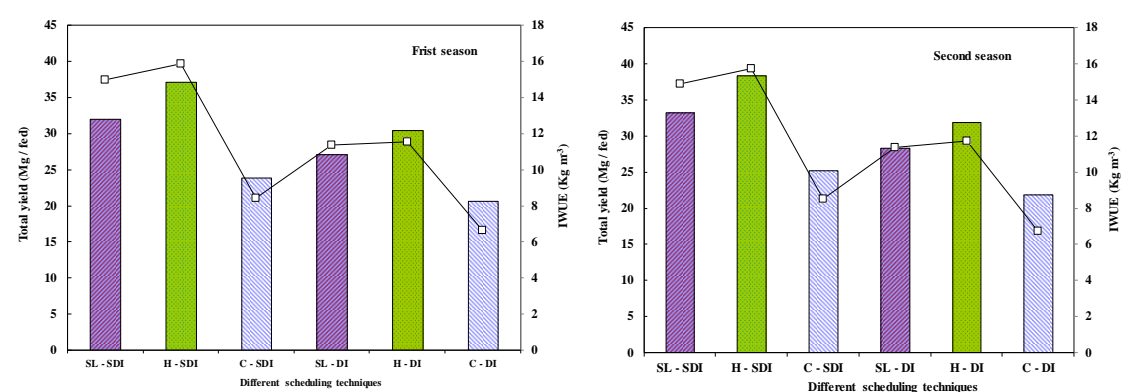

Fig. (4). Tomatoes yields and IWUE vs. the treatments different scheduling techniques or the amount of irrigation water applied for the first and second seasons.

\section{CONCLUSION}

This study was conducted in Riyadh, Saudi Arabia, to evaluate the effectiveness of two smart systems, based on the amount of irrigation water applied. In particular, the study aimed to improve the use of water, which is critical for the sustainability of irrigated farming supported by DI and SDI systems in arid regions.

The obtained results revealed that, different amounts of water were added to the tomato crop and that resulting in different yield between the three irrigation scheduling methods. Moreover, it is clear that plant growth parameters and water conservation were affected most significantly by the 
Hunter controller under SDI, thus the water was used most efficiently by this treatment combination. Therefore, applying irrigation according to this technique provides significant advantages in terms of both crop yield and IWUE. In particular, the Hunter controller was able to converse $25 \%$ more irrigation water than the control treatment, while simultaneously generating higher total yields.

The methods presented in this study represent considerable progress toward the goal of integrated water management in arid regions, because SICs offer potential for efficient irrigation by conserving water while maintaining acceptable quality and increasing yield. In fact, ET controllers offer the potential for water savings of $50 \%$ as compared with conventional irrigation scheduling methods. To obtain the full benefits of these smart irrigation technologies, a comprehensive tomato crop management program should be established and an efficient irrigation system maintained.

\section{ACKNOWLEDGMENT}

The researchers wish to thank The National Plan for Science and Technology (King Saud University in cooperation with King Abdul-Aziz City for sciences and Technology) for providing funds to undertake this study through Grant No. 11-AGR1476-02.

\section{REFERENCES}

Acar, B,; Topak, R.; and Direk, M. (2010). "Impacts of Pressurized Irrigation Technologies on Efficient Water Resources Uses in Semi-Arid Climate of Konya Basin of Turkey" Int. J. of Sustainable Water \& Environmental Systems 1(1): 1-4.

Al-Ghobari, H. M.; and Fawzi, S. M.; (2011). "Intelligent irrigation performance: evaluation and quantifying its ability for conserving water in arid region" Springer, J. Applied Water Science, 1: 73-83.

Al-Ghobari, H. M.; Mohammad and M. S. A. El Marazky ( 2013). Effect of intelligent irrigation on water use efficiency of wheat crop in arid region. Animal and Plant Sciences Journal, 23(6): 1691-1699.

Allen G. R., S. L. Pereira, R.; Dirk and Martin, S.; (1998). "Crop evapotranspiration-guidelines for computing crop water requirements" FAO Irrigation and Drainage. In FAO Paper No 56 irrigation and drainage, Rome, pp 7-28.

Al-Omran, A. M., A. R;. AL-Harbi, M. A. Wahb-Allah, M. Nadeem and ALEter, A.; (2010)." Impact of irrigation water quality, irrigation systems, irrigation rates and soil amendments on tomato production in sandy calcareous soil" Turk J Agric For, 34: 59-73.

American Society of Agricultural And Biological Engineers (ASABE) Standard S436.1. 2007. Test procedure for determining the uniformity of water 
distribution of center pivot and lateral move irrigation machines equipped with spray or sprinkler nozzles. ASABE, St. Joseph.

AOAC. (1995). Official Methods of Analysis. $13^{\text {th }}$ Ed. Washington, D.C., Association of Official Analytical Chemists.

Dassanayake, D. K., H.; Dassanayake, G. M.; Malano, P.; Dunn Douglas and J. Langford (2009). "Water saving through smarter irrigation in Australian dairy farming: use of intelligent irrigation controller and wireless sensor network" 18th World IMACS/MODSIM Congress, Cairns, Australia, pp 4409-4417.

Davis S. L.; and. Dukes, M. D.; (2012).: Landscape irrigation with evapotranspiration controller in a humid climate" Trans. ASABE. 55: 571-580.

Davis, S. L..; Dukes, M. D.; and Miller, G. L.; (2010.). "Irrigation scheduling performance by evapotranspiration-based controllers" Agricultural Water Management 98: 19-28.

Dukes M. D.; Zotarelli, L.; and Morgan K. T.; (2010). "Use of irrigation technologies for vegetable crops in Florida." Horttechnology, 20 (1), 133-142.

Evett, S. R. (2008).Neutron moisture meters; In Field Estimation of Soil Water Content : A Practical Guide to Methods, Instrumentation, and Sensor Technology.

Ezzo MI, Glala A. A.; Habib HA.; andHelaly, A. A.; (2010). "Response of sweet pepper grown in sandy and clay soil lysimeters to water regime". Amer-Euras J Agric \& Environ Sci; 8:18-26.

Green, G., D. Sunding, D. Zilberman and D. Parker (1996). Explaining irrigation technology choices: a microparameter approach. Am. J. Agric. Econ, 78: 1064-1072.

Hassanli, A. M., M. A. Ebrahimizadeh and Beecham, S.; (2009). "The effects of irrigation methods with effluent and irrigation scheduling on water use efficiency and corn yields in an arid region"Agricultural Water Management 96: 93 -99.

IA, Irrigation Association (2011). Smart Water Application Technologies (SWAT) program. Falls Church, Va.: Irrigation Association. Available at:www.irrigation.org/SWAT/.Accessed 13 December 2010.

Jones, H. (2004) Irrigation scheduling: advantages and pitfalls of plant based methods. J Exp Bot, 55:2427-2436.

Khairy, M. F. A.; Elmeseery, A. A.; and Abdel- Aziz, A. A.;(2009). "Trickle irrigation utilization for tomato in sandy soil" Misr. J. Ag. Eng., 26: 170 $-185$.

Locascio, S. J.; (2005). "Management of irrigation for vegetables: Past, present, and future." Horttechnology, 15(3), 482-485.

Mayer, P., W. DeOreo, Hayden, M.; Davis, R.; Caldwell, E.; Miller, T.; and Bickel, P. J. (2009). Evaluation of California weather-based "smart" irrigation controller programs"

Michael, A. (1978)." Irrigation and theory practice "Vikas Pub. House PVT LTD, New Delihi. 
Mohammad F. S.; Al-Ghobari, H. M.; and El Marazky M. S. A.;(2013) "Adoption of intelligent irrigation scheduling technique and its effect on water use efficiency of tomato crops in arid regions" Australian of Crop Science Journal 3:305-313.

Muñoz-Carpena, R.; and Dukes,V.; (2005a). "Automatic Irrigation Based on Soil Moisture for Vegetable Crops" Fact Sheet ABE 356 of the Dept. of Agr. and Bio. Engineering, University of Florida.

Muñoz-Carpena, R.; Bryan,V.; Klassen, W.; Dispenza, T. T.; and Dukes, M. D.; (2003). "Evaluation of an automatic soil moisture-based drip irrigation system for row tomatoes" Presented at the 27-30 July ASABE Annual International Meeting, Paper No. 032093. Las Vegas, Nevada, USA.

Muñoz-Carpena, R.; Dukes, M. D.; Li, V. C.; and Klassen, W.; (2005b)" Field comparison of tensiometer and granular matrix sensor automatic drip irrigation on tomato" HortTechnology 15:584-590.

Norum, M. N.; and Adhikari, D. (2009) "Smart irrigation system controllers. In: 7th World Congress on computers in agriculture conference proceedings" Reno, Nevada. ASABE, St. Joseph, Michigan.

Patane C, S, Tringali and Sortino, O. (2011). "Effects of deficit irrigation on biomass, yield, water productivity and fruit quality of processing tomato under semi-arid Mediterranean climate conditions" Sci Hort; 129:590-596.

SAS. (2008.). (Statistical Analysis System) Institute. The SAS System for Windows. Release 9. 0. Cary, NC, USA.

Steel, R. G.; and Torrie, J. H.; (1980). "Principles and procedures of statistics" McGraw-Hill, New York.

Turhan A,; and Seniz, V. (2009). "Estimation of certain chemical constituents of fruits of selected tomato genotypes grown in Turkey" Afr J Agric Res; 4(10):1086-1092.

Vellidis, G.; Tucker, M.; Perry, C. Wen, C.; and Bednarz, C.; ( 2008)." A realtime wireless smart sensor array for scheduling irrigation" Comput. Electron. Agric, 61: 44-50.

Wang, J. D.; Gong, S.; and Gao, Z.; (2009)." Effects of drip irrigation mode on spatial distribution of soil water and nitrate and winter tomato yield (in Chinese)" Trans of the CSAE, 25(11): 67-72.

Zotarelli, L.; Scholberg, J. M.; Dukes, M. Muñoz-Carpena, D.; and Icerman, J.; (2009) "Tomato yield, biomass accumulation, root distribution and irrigation water use efficiency on a sandy soil, as affected by nitrogen rate and irrigation scheduling" Agric. Water Manage. 96(1):23-34. 
EI Marazky, M. S. A.

تأثير وحدات تحكم الري الذكي على أداء و إنتاجية الري بالتنقيط السطحي والتحت

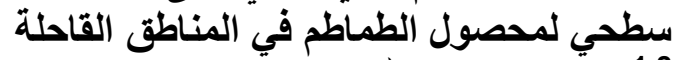

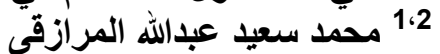

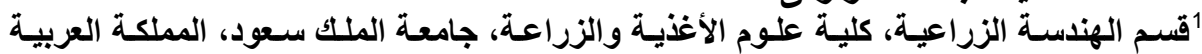

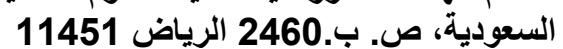
2معهز بحوث الهنسة الزراعية، مركز البحوث الزراعية، ج. م. ع.

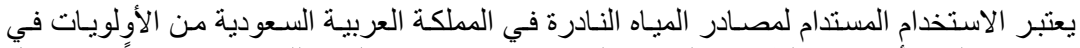

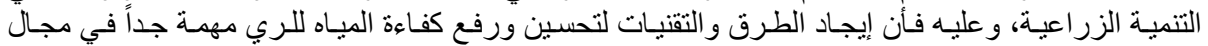

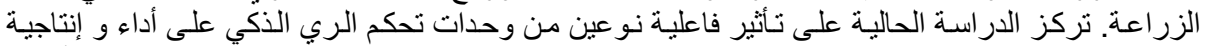

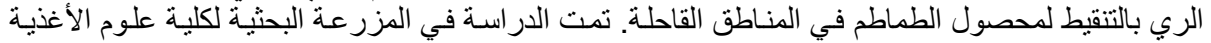

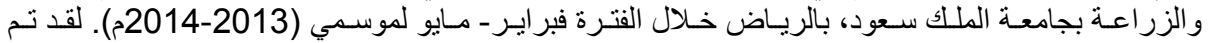
[SmartLine, SL-1600 (SL) and Hunter Pro-C (H)] استخدام نو عين من تقنيات التحكم الآلكي الرئي

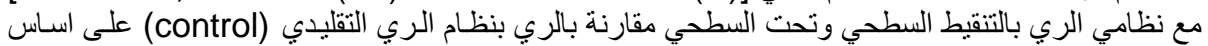

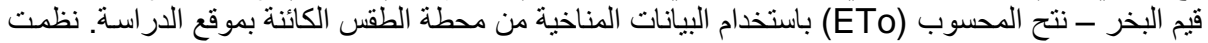

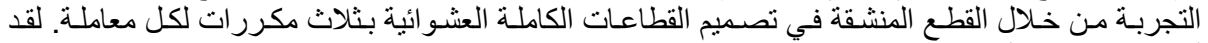

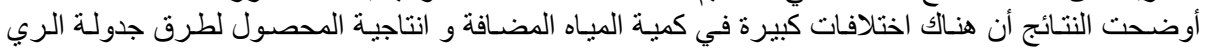

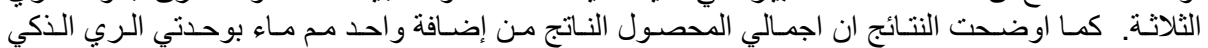
Hunter Pro-C (H) and SmartLine, SL-1600 (SL)

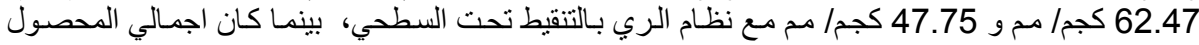

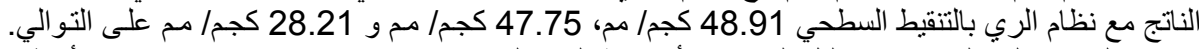

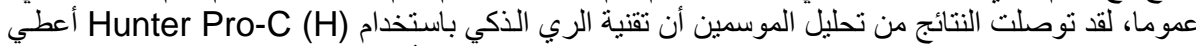

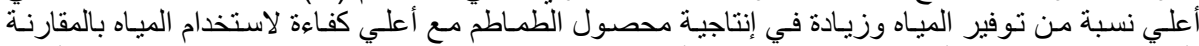

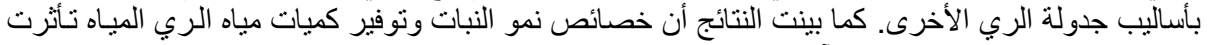

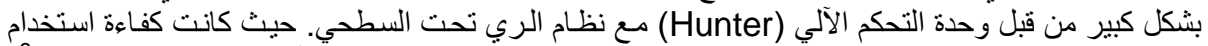

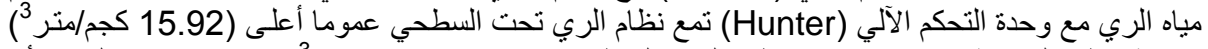

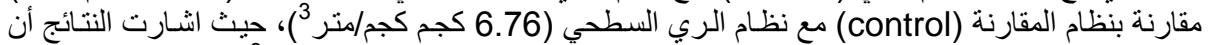

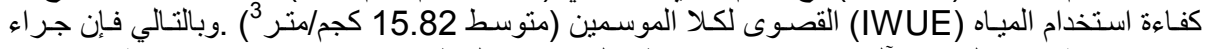

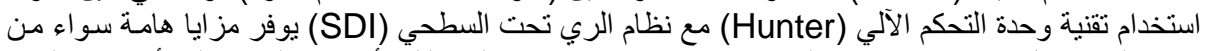

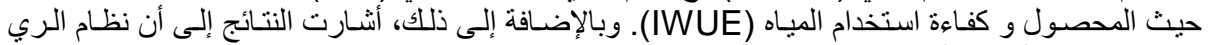

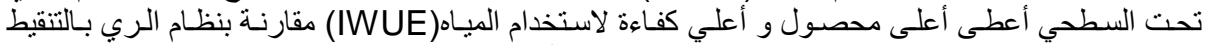

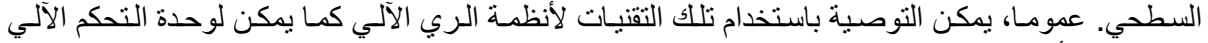

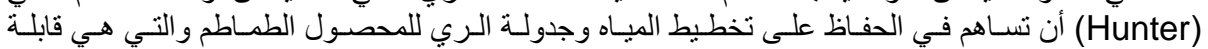
للاستخدام مع المحاصيل الزئ أنية الأخرى المماتلة. 